\title{
Natural radioactivity and associated radiation hazards of some commonly used building materials in southwest Nigeria
}

\author{
M.O. ISINKAYE ${ }^{1 *}$, J.I. AGBI ${ }^{2}$
}

(Manuscript received 9 November 2012, accepted 6 March 2013)

ABSTRACT The activity concentrations of primordial radionuclides $\left({ }^{40} \mathrm{~K},{ }^{226} \mathrm{Ra}\right.$ and $\left.{ }^{232} \mathrm{Th}\right)$ in five different types of commonly used building materials in southwest Nigeria were measured using a low-background $\mathrm{NaI}(\mathrm{Tl})$ detector coupled to an IBM-compatible multichannel analyzer. The highest mean concentration of ${ }^{40} \mathrm{~K}$, which was $887.5 \pm$ $101.3 \mathrm{~Bq} \cdot \mathrm{kg}^{-1}$, was obtained in gravel. Also, the highest mean concentrations of ${ }^{226} \mathrm{Ra}$ and ${ }^{232} \mathrm{Th}$ were obtained, respectively, in sand and brick samples. The lowest mean concentrations of ${ }^{40} \mathrm{~K},{ }^{226} \mathrm{Ra}$ and ${ }^{232} \mathrm{Th}$, respectively, were obtained in brick and cement sample. The annual gonadal effective dose (AGED) and other radiological parameters were estimated from the activity concentrations of the radionuclides. The highest mean values of the AGED and radium equivalent activity concentration obtained were $359.1 \mu \mathrm{Sv} . \mathrm{y}^{-1}$ and $110.9 \mathrm{~Bq} \cdot \mathrm{kg}^{-1}$, respectively. All these radiological parameters were below the maximum permissible levels recommended for safe use of materials in building construction. It can therefore be concluded that these materials do not pose any radiological hazard to the dwellers of buildings constructed with them.

Keywords: building materials / primordial radionuclides / radiation hazards / NaI(Tl) detector

\section{Introduction}

All building materials derived from soil and rocks contain certain concentrations of natural radioactive substances. Naturally occurring radioactive materials are known to be the largest contributor to human radiation exposure (UNSCEAR, 2011). These include the radioactive substances in the uranium and thorium decay series $\left({ }^{238} \mathrm{U}\right.$ and $\left.{ }^{232} \mathrm{Th}\right)$ with their respective decay progenies, and the radioactive isotope of potassium $\left({ }^{40} \mathrm{~K}\right)$. In the uranium decay series, the decay chain segment starting from radium $\left({ }^{226} \mathrm{Ra}\right)$ is radiologically most important and, therefore, reference is often made to ${ }^{226} \mathrm{Ra}$ instead of ${ }^{238} \mathrm{U}$. In addition to naturally occurring radioactive materials, some industrial by-products also contain artificial radionuclides such as ${ }^{137} \mathrm{Cs}$, which are spread into the environment due to the fallout from nuclear weapon tests and industrial nuclear accidents, e.g. the Chernobyl

Department of Physics, Ekiti State University, P.M.b. 5363, Ado Ekiti, Nigeria.

Department of Physics, Adekunle Ajasin University, Akungba Akoko, Nigeria.

* e-mail: niyikaye2002@yahoo.com 
accident of 1986 (STUK, 2010). The contribution of artificial radionuclides to human exposure in the environment is known to be far smaller in comparison with the contribution from natural radionuclides (UNSCEAR, 2011).

Natural radionuclides in building materials can cause both external exposure due to direct gamma radiation and internal radiation exposure from radon gas (Mehdizadeh et al., 2011). Radon is an alpha particle emitter with energy $5.48 \mathrm{MeV}$, a half-life of 3.82 days and a daughter product of ${ }^{226} \mathrm{Ra}$. It is chemically inert and can move through the earth and structural materials to reach the outdoor atmosphere and indoor spaces (Nazaroff and Nero, 1988; Kobeissi et al., 2008). Its accumulation indoors in rooms is believed to form more than $50 \%$ of the dose equivalent received through inhalation by the general public from all sources of radiation exposure (Kobeissi et al., 2008). Exposure to high concentrations of radon gas and its progeny for a long period of time can cause pathological effects and the occurrence of lung cancer (BEIR, 1999). The radiation which humans are exposed to may increase appreciably if they live in houses constructed using materials whose radiation doses are above the normal background radiation level of the area (Cliff et al., 1985; Otoo et al., 2011).

Knowledge of the distribution pattern of natural radionuclides in building materials is very important due to the fact that building materials constitute the largest source of population exposure because humans spend most of their time indoors. The results of radioactivity measurements in building materials help in setting up radiation protection guidelines and aid in decision-making processes. They also assist in the implementation of precautionary measures whenever the dose level is found to be above recommended limits. However, in Nigeria, there is virtually no regulation currently controlling the use of materials in relation to their radioactivity levels. During the last three decades, there has been increased interest in the study of the radioactivity levels of diverse building materials. Several national and regional surveys have been conducted to establish the radioactivity concentrations and radiological impact of various building materials such as sand, bricks, concrete, granite, cement, ceramic tiles, clay, etc. (Ingersoll, 1983; Berekta and Matthew, 1985; Malanca et al., 1993; Hewamanna et al., 2001; Khan and Khan, 2001; Stoulos et al., 2003; Xinwei, 2004; Papastefanou et al., 2005; Xinwei, 2005; Al-Jundi et al., 2006; Tufail et al., 2007; Bridigo Flores et al., 2008; Turhan et al., 2008; Righi et al., 2009; Hassan et al., 2010; Stojanovska et al., 2010; Otoo et al., 2011; etc.). In Nigeria, a few studies have focused on the radioactivity levels of building materials (Farai and Ademola, 2005; Farai and Ejeh, 2006; Farai and Isinkaye, 2009). This recent work is therefore aimed at evaluating the activity concentration of five commonly used building materials; cement, gravel, bricks, ceramic tiles and sand, in order to estimate the radiological problems associated with their use in constructing houses in southwest Nigeria. 


\section{Materials and methods}

Samples of different commonly used building materials were collected from five cities (Abeokuta, Ado Ekiti, Akure, Lagos and Osogbo) in southwest Nigeria. The samples consist of sand, gravel, cement (which includes two popular brands, Dangote and Portland cement), ceramic tiles and bricks. The ceramic tiles used in southwest Nigeria are imported mainly from China, Spain and Italy, while the cements are produced locally with some imported additives. The Spanish and Italian tiles are seldom used due to high cost. The building materials were collected randomly from different brick-making industries and building construction sites, except ceramic tiles, which were obtained from the retailers. Each sample was taken to the laboratory, pulverized and homogenized in order to have the same matrix and characteristics as the standard sample. They were then packed into cylindrical thin-walled plastic containers whose dimensions are $7.5 \mathrm{~cm} \times 6.5 \mathrm{~cm}$ in height and diameter, respectively.

The sealed samples were then left for about 28 days in order to achieve secular equilibrium between ${ }^{226} \mathrm{Ra}$ and its progeny, as well as between ${ }^{232} \mathrm{Th}$ and its own progeny. Since radium $\left({ }^{226} \mathrm{Ra}\right.$ ) and its progeny produce $98.5 \%$ of the radiological effects of the uranium series, the contributions of ${ }^{238} \mathrm{U}$ and the precursors of ${ }^{226} \mathrm{Ra}$ are normally ignored (Hassan et al., 2010). Therefore, the reference of the uranium series is often ${ }^{226} \mathrm{Ra}$ rather than ${ }^{238} \mathrm{U}$ (Farai and Ademola, 2005).

The activity concentrations of ${ }^{226} \mathrm{Ra},{ }^{232} \mathrm{Th}$ and ${ }^{40} \mathrm{~K}$ were measured using a low-background $\mathrm{Nal}(\mathrm{Tl})$ detector coupled to an IBM-compatible multichannel analyzer with Sampo 90 software for data analysis. The detector was calibrated using ${ }^{109} \mathrm{Cd},{ }^{57} \mathrm{Co},{ }^{137} \mathrm{Cs},{ }^{54} \mathrm{Mn}$ and ${ }^{22} \mathrm{Na}$ for their known energy and peak width of $\gamma$-ray emissions, while the counting efficiency was determined using a standard soil sample (IAEA soil-375) obtained from the IAEA, Vienna Austria. The radionuclides were identified according to their individual photo peaks, which are $1.76 \mathrm{MeV}\left({ }^{214} \mathrm{Bi}\right)$ for ${ }^{226} \mathrm{Ra}, 2.62 \mathrm{MeV}\left({ }^{208} \mathrm{Tl}\right)$ for ${ }^{232} \mathrm{Th}$ and $1.4603 \mathrm{MeV}$ for ${ }^{40} \mathrm{~K}$ (Yasir et al., 2007). The activity concentration of individual radionuclides was obtained by direct comparison of the total counts per second (cps) obtained from individual samples of the building materials with the count per second (cps) obtained for the same radionuclide in the standard sample. The activity concentration was obtained using the following equation:

$$
\mathrm{C}_{\mathrm{s}}=\frac{\mathrm{A}_{\mathrm{s}} \mathrm{M}_{\text {std }}}{\mathrm{A}_{\mathrm{std}} \mathrm{M}_{\mathrm{s}}} \mathrm{C}_{\text {std }}
$$

where $\mathrm{C}_{\mathrm{S}}$ is the concentration of the radionuclide in the analyzed sample $\left(\mathrm{Bq} \cdot \mathrm{kg}^{-1}\right)$, $\mathrm{C}_{\mathrm{std}}$ is the concentration of the radionuclide in the standard sample (Bq. $\left.\mathrm{kg}^{-1}\right), \mathrm{M}_{\mathrm{s}}$ is the mass of the analyzed sample $(\mathrm{g}), \mathrm{M}_{\text {std }}$ is the mass of the standard sample (g), 
TABLE I

Activity concentrations of ${ }^{40} \mathrm{~K},{ }^{226} \mathrm{Ra}$ and ${ }^{322} \mathrm{Th}$ measured in different types of building materials used in southwest Nigeria.

\begin{tabular}{|c|c|c|c|c|}
\hline \multirow[b]{2}{*}{$\begin{array}{c}\text { Type of } \\
\text { building } \\
\text { material }\end{array}$} & \multirow[b]{2}{*}{$\begin{array}{l}\text { No of } \\
\text { sample }\end{array}$} & \multicolumn{3}{|c|}{ Activity concentration $\left(\mathrm{Bq} \cdot \mathrm{kg}^{-1}\right)$} \\
\hline & & $\begin{array}{c}{ }^{40} \mathrm{~K} \\
\text { Range } \\
\text { (Mean) }\end{array}$ & $\begin{array}{l}{ }^{226} \mathrm{Ra} \\
\text { Range } \\
\text { (Mean) }\end{array}$ & $\begin{array}{l}{ }^{232} \mathrm{Th} \\
\text { Range } \\
\text { (Mean) }\end{array}$ \\
\hline Cement & 15 & $\begin{array}{c}3.7-722.7 \\
(218.7 \pm 11.5)\end{array}$ & $\begin{array}{c}8.7-217.0 \\
(58.9 \pm 12.2)\end{array}$ & $\begin{array}{c}4.7-45.9 \\
(16.3 \pm 3.9)\end{array}$ \\
\hline Tiles & 15 & $\begin{array}{c}160.7-854.1 \\
(397.9 \pm 41.0)\end{array}$ & $\begin{array}{c}7.8-115.2 \\
(40.1 \pm 12.0)\end{array}$ & $\begin{array}{c}6.3-51.9 \\
(19.2 \pm 3.3)\end{array}$ \\
\hline Gravel & 15 & $\begin{array}{c}38.6-887.5 \\
(400.9 \pm 42.4)\end{array}$ & $\begin{array}{c}6.4-110.2 \\
(39.8 \pm 12.5)\end{array}$ & $\begin{array}{c}3.7-50.8 \\
(17.3 \pm 4.0)\end{array}$ \\
\hline Bricks & 15 & $\begin{array}{c}10.2-611.2 \\
(193.5 \pm 20.5)\end{array}$ & $\begin{array}{c}4.4-113.9 \\
(33.2 \pm 11.7)\end{array}$ & $\begin{array}{l}2.6-132.3 \\
(27.4 \pm 4.0)\end{array}$ \\
\hline Sand & 10 & $\begin{array}{l}22.0-641.9 \\
(274.7 \pm 4.3)\end{array}$ & $\begin{array}{c}6.4-152.5 \\
(61.3 \pm 23.2)\end{array}$ & $\begin{array}{l}10.5-33.5 \\
(20.0 \pm 3.1)\end{array}$ \\
\hline
\end{tabular}

$A_{s}$ is the count rate (cps) of the analyzed sample, and $A_{\text {std }}$ is the count rate of the standard sample (cps).

\section{Results and discussion}

The specific activities of the measured radionuclides, i.e. ${ }^{40} \mathrm{~K},{ }^{226} \mathrm{Ra}$ and ${ }^{232} \mathrm{Th}$, in the five commonly used building materials in southwest Nigeria expressed in Bq. $\mathrm{kg}^{-1}$ dry mass of the samples are presented in Table I. The activity concentration of ${ }^{40} \mathrm{~K}$ ranged from 3.7-887.5 Bq. $\mathrm{kg}^{-1},{ }^{226} \mathrm{Ra}$ ranged from 4.4-217.0 Bq. $\mathrm{kg}^{-1}$ and that of ${ }^{232} \mathrm{Th}$ ranged from $2.6-132.3 \mathrm{~Bq} \cdot \mathrm{kg}^{-1}$ in all the analyzed samples. The highest mean concentrations of ${ }^{40} \mathrm{~K},{ }^{226} \mathrm{Ra}$ and ${ }^{232} \mathrm{Th}$ are found in gravel, sand and bricks, respectively, while the lowest mean concentrations of the three radionuclides, respectively, are found in brick and cement samples, as shown in Table I. When compared with the results from other locations around the world, the mean activity concentrations of the radionuclides in the five different building materials analyzed in this study are comparable with the values reported in the literature. Table II presents the comparison of the results of the present work with values obtained by different researchers from other countries. It is observed that the activity concentration of ${ }^{40} \mathrm{~K}$ in cement is lower in this study than most of the values from the other countries considered, except Australia and China. ${ }^{226} \mathrm{Ra}$ concentrations are higher in this study than the results from other countries, except Brazil, while the ${ }^{232}$ Th concentrations obtained for cement in this study are lower than the values from other countries, except Greece. For tiles, the concentrations of ${ }^{40} \mathrm{~K},{ }^{226} \mathrm{Ra}$ and ${ }^{232} \mathrm{Th}$ are all lower than the values from most countries. The trend in bricks is similar to that of tiles, but concentrations of ${ }^{40} \mathrm{~K},{ }^{226} \mathrm{Ra}$, and ${ }^{232} \mathrm{Th}$ in gravel are higher in value compared with the concentrations obtained in other countries. 
TABLE II

Comparison of activity concentrations of ${ }^{40} \mathrm{~K},{ }^{226} \mathrm{Ra}$ and ${ }^{232} \mathrm{Th}$ in building materials analyzed in this study with values from other countries.

\begin{tabular}{|c|c|c|c|c|c|}
\hline $\begin{array}{c}\text { Type of } \\
\text { building } \\
\text { materials }\end{array}$ & Country & ${ }^{40} K$ & ${ }^{226} \mathrm{Ra}$ & ${ }^{232} \mathrm{Th}$ & Reference \\
\hline \multirow{12}{*}{ Cement } & Algeria & 422.0 & 41.0 & 27.0 & Amrani and Tahtat (2001) \\
\hline & Australia & 114.7 & 51.8 & 48.1 & Berekta and Matthew (1985) \\
\hline & Brazil & 564.0 & 61.7 & 58.5 & Malanca et al. (1993) \\
\hline & China & 173.2 & 56.5 & 36.5 & Xinwei (2005) \\
\hline & Greece & 241.0 & 20.0 & 13.0 & Stoulos et al. (2003) \\
\hline & India & 432.2 & 37.0 & 24.1 & Kumar et al. (1999) \\
\hline & Iran & 290.8 & 39.6 & 28.9 & Mehdizadeh et al. (2011) \\
\hline & Italy & 218 & 38 & 22 & Rizzo et al. (2001) \\
\hline & Netherlands & 230.0 & 27.0 & 19.0 & Ackers et al. (1985) \\
\hline & Macedonia & $264 \pm 50$ & $42 \pm 10$ & $28 \pm 8$ & Stojanovska et al. (2010) \\
\hline & Turkey & $267 \pm 102$ & $41 \pm 27$ & $26 \pm 19$ & Turhan (2007) \\
\hline & Nigeria & $218.7 \pm 11.5$ & $58.9 \pm 12.2$ & $16.2 \pm 3.9$ & Present study \\
\hline \multirow{8}{*}{ Tiles } & Algeria & 410.0 & 55.0 & 41.0 & Amrani and Tahtat (2001) \\
\hline & China & 480.0 & 73.0 & 62.0 & Xinwei (2004) \\
\hline & Egypt & 569.0 & 77.0 & 64.0 & Higgy et al. (2000) \\
\hline & Greece & $411-786$ & $25-174$ & $29-47$ & Kristić et al. (2007) \\
\hline & India & 24 & 28 & 64 & Kumar et al. (2003) \\
\hline & Italy & 708.0 & 53 & 53 & Righi et al. (2009) \\
\hline & Pakistan & 476.9 & 70.3 & 62.1 & Turhan et al. (2008) \\
\hline & Nigeria & $397.9 \pm 41.0$ & $40.1 \pm 12.0$ & $19.1 \pm 3.4$ & Present study \\
\hline \multirow{6}{*}{ Gravel } & Australia & 171.0 & 13.9 & 14.8 & Soranin and Steger (1983) \\
\hline & Brazil & 933.0 & 10.3 & ND & Malanca et al. (1993) \\
\hline & Iran & 450.0 & 20.4 & 6.3 & Mehdizadeh et al. (2011) \\
\hline & Lebanon & 4.6 & 27.5 & 13.8 & Kobeissi et al. (2008) \\
\hline & USA & 14.8 & 33.3 & 33.3 & Ingersoll (1983) \\
\hline & Nigeria & $400.9 \pm 42.4$ & $39.8 \pm 12.5$ & $17.3 \pm 4.0$ & Present study \\
\hline \multirow{8}{*}{ Bricks } & Algeria & 675 & 65 & 51 & Amrani and Tahtat (2001) \\
\hline & China & 714 & 59 & 50 & Xinwei (2005) \\
\hline & Greece & 710 & 35 & 45 & Papaefthymiou and Gouseti (2008) \\
\hline & Iran & $851.4 \pm 15$ & $37.0 \pm 1.5$ & $12.2 \pm 0.7$ & Mehdizadeh et al. (2011) \\
\hline & Kuwait & 332 & 12 & 7 & Bou-Rabee and Bem (1996) \\
\hline & Pakistan & 692.63 & 45.50 & 61.76 & Tufail et al. (2007) \\
\hline & Turkey & $923.4 \pm 161.0$ & $69.9 \pm 11.7$ & 11.7 & Turhan et al. (2008) \\
\hline & Nigeria & $193.5 \pm 20.5$ & $33.2 \pm 11.7$ & $27.4 \pm 4.0$ & Present study \\
\hline
\end{tabular}


TABLE II

Continued.

\begin{tabular}{cccccc}
\hline $\begin{array}{c}\text { Type of building } \\
\text { materials }\end{array}$ & Country & ${ }^{\mathbf{4 0}} \mathbf{K}$ & ${ }^{\mathbf{2 2 6}} \mathbf{R a}$ & ${ }^{\mathbf{2 3 2}} \mathbf{T h}$ & Reference \\
\hline & Algeria & $74 \pm 7$ & $12 \pm 1$ & $7 \pm 1$ & Amrani and Tahtat (2001) \\
& Bangladesh & $303.1 \pm 141.9$ & $14.5 \pm 8.2$ & $34.7 \pm 2.4$ & Mantazul et al. (1998) \\
& Brazil & 51 & 10.2 & 12.6 & Malanca et al. (1993) \\
& Cameroon & $586 \pm 13$ & $14 \pm 1$ & $31 \pm 1$ & Ngachin et al. (2007) \\
& Greece & $367 \pm 204$ & $18 \pm 7$ & $17 \pm 10$ & Stoulos et al. (2003) \\
& India & 65.5 & 9.4 & 52.05 & Kumar et al. (2003) \\
& Kuwait & $360 \pm 14$ & $7.9 \pm 0.7$ & $7.2 \pm 0.3$ & Bou-Rabee and Bem (1996) \\
& Turkey & $527.2 \pm 129.2$ & $22.9 \pm 12.9$ & $26.4 \pm 16.2$ & Turhan et al. (2008) \\
& Zambia & $714 \pm 17$ & $24 \pm 1$ & $26 \pm 2$ & Hayambu et al. (1995) \\
& Nigeria & $274.7 \pm 4.3$ & $61.3 \pm 23.2$ & $20.0 \pm 3.1$ & Present study \\
\hline
\end{tabular}

\section{Estimation of radiological hazard indices}

The measured activity concentrations of the natural radionuclides in the building materials were used to estimate the radiological hazards associated with the use of such materials in building construction. The radiation hazard parameters estimated in this study include: radium equivalent activity, the internal hazard index $\left(\mathrm{H}_{\mathrm{in}}\right)$, the gamma index $\left(\mathrm{I}_{\gamma}\right)$, the alpha index $\left(\mathrm{I}_{\alpha}\right)$ and the annual gonadal equivalent dose (AGED).

The radium equivalent activity $\left(\mathrm{Ra}_{\mathrm{eq}}\right)$ is a common index used to represent the activity concentrations of ${ }^{226} \mathrm{Ra},{ }^{232} \mathrm{Th}$ and ${ }^{40} \mathrm{~K}$ by a single quantity, which takes into account all the radiation hazards associated with the materials. It is calculated based on the estimation that 370 Bq. $\cdot \mathrm{kg}^{-1}$ of ${ }^{226} \mathrm{Ra}, 259 \mathrm{~Bq} \cdot \mathrm{kg}^{-1}$ of ${ }^{232} \mathrm{Th}$ and $4.810 \mathrm{~Bq} \cdot \mathrm{kg}^{-1}$ of ${ }^{40} \mathrm{~K}$ produce the same gamma-ray dose rate. The radium equivalent activity is expressed as:

$$
\mathrm{Ra}_{\mathrm{eq}}=\mathrm{A}_{\mathrm{Ra}}+1.43 \mathrm{~A}_{\mathrm{Th}}+0.077 \mathrm{~A}_{\mathrm{K}},
$$

where $A_{R a}, A_{T h}$ and $A_{K}$ are the activity concentrations of ${ }^{226} \mathrm{Ra},{ }^{232} \mathrm{Th}$ and ${ }^{40} \mathrm{~K}$, respectively, in Bq. $\mathrm{kg}^{-1}$. In order to limit the external dose to below $1.5 \mathrm{mSv}$ per year, indicating safe use of any material in building construction, the radium equivalent must be less than 370 Bq. $\mathrm{kg}^{-1}$ (UNSCEAR, 2000). The calculated $\mathrm{Ra}_{\mathrm{eq}}$ for the building material samples considered in this study is presented in Table III. It is observed that the $\mathrm{Ra}_{\mathrm{eq}}$ for the locally sourced materials and the imported ceramic tiles are all below the maximum permissible limit of $370 \mathrm{~Bq} \cdot \mathrm{kg}^{-1}$. It can therefore 
TABLE III

Range and mean values of calculated radiation hazard parameters in building materials.

\begin{tabular}{|c|c|c|c|c|c|c|c|c|c|c|}
\hline \multirow{3}{*}{$\begin{array}{c}\text { Type of } \\
\text { building } \\
\text { material }\end{array}$} & \multicolumn{10}{|c|}{ Radiation hazard parameters } \\
\hline & \multicolumn{2}{|c|}{$\mathbf{R a}_{\mathrm{eq}}$} & \multicolumn{2}{|l|}{$I_{\gamma}$} & \multicolumn{2}{|c|}{$\mathbf{H}_{\text {in }}$} & \multicolumn{2}{|l|}{$I_{\alpha}$} & \multicolumn{2}{|l|}{ AGED } \\
\hline & Range & Mean & Range & Mean & Range & Mean & Range & Mean & Range & Mean \\
\hline Cement & $17.9-310.4$ & $99.0 \pm 18.7$ & $0.06-1.10$ & 0.35 & $0.07-1.35$ & 0.43 & $0.04-1.08$ & 0.29 & $54.3-1003.2$ & 318.5 \\
\hline Tiles & $34.7-208.8$ & $98.1 \pm 19.9$ & $0.13-0.73$ & 0.36 & $0.12-0.87$ & 0.37 & $0.04-0.58$ & 0.20 & $121.1-651.7$ & 328.9 \\
\hline Gravel & $11.7-227.7$ & $93.2 \pm 21.4$ & $0.04-0.82$ & 0.34 & $0.05-0.91$ & 0.36 & $0.03-0.55$ & 0.19 & $35.3-735.8$ & 312.1 \\
\hline Bricks & $13.4-266.9$ & $84.7 \pm 18.7$ & $0.05-0.93$ & 0.30 & $0.05-0.93$ & 0.32 & $0.02-0.56$ & 0.17 & $41.0-799.1$ & 270.4 \\
\hline Sand & $73.6-232.2$ & $110.9 \pm 27.9$ & $0.27-0.81$ & 0.40 & $0.22-1.04$ & 0.47 & $0.03-0.76$ & 0.31 & $243.9-741.1$ & 359.1 \\
\hline
\end{tabular}

TABLE IV

Comparison of radium equivalent activity with values obtained by other researchers.

\begin{tabular}{|c|c|c|c|c|c|c|}
\hline \multirow{2}{*}{ Country } & \multicolumn{5}{|c|}{ Radium equivalent activity $\left(\mathrm{Bq} \cdot \mathrm{kg}^{-1}\right)$} & \multirow{2}{*}{ Reference } \\
\hline & Cement & Tiles & Gravel & Bricks & Sand & \\
\hline Algeria & 112 & 145 & 58 & 190 & 28 & Amrani and Tahta (2001) \\
\hline Bangladesh & 172.8 & - & 121.29 & 127.14 & 87.52 & Mantazul et al. (1998) \\
\hline Cameroon & 70.1 & 36.03 & 80.12 & 193.34 & 94.7 & Ngachin et al. (2007) \\
\hline China & 128 & - & 79 & 95 & 202 & Xinwei (2004) \\
\hline Cuba & 78 & - & 49 & 140 & 55 & Brigido Flores et al. (2008) \\
\hline India & - & 121 & 72.1 & 69.15 & 135 & Kumar et al. (2003) \\
\hline Iran & 103.32 & - & 64.11 & 58.58 & - & Mehdizadeh et al. (2011) \\
\hline Lebanon & 92.2 & - & 28.4 & - & 23 & Kobeissi et al. (2008) \\
\hline Malaysia & 69.6 & 93.7 & - & 130.7 & 102.6 & Yasir et al. (2007) \\
\hline Pakistan & 69 & - & - & 106 & 91 & Faheem et al. (2008) \\
\hline Turkey & 101.9 & 195.8 & 95.6 & 240.4 & 101.2 & Turhan et al. (2008) \\
\hline Zambia & 79 & - & 33 & 180 & 84.15 & Hayambu et al. (1995) \\
\hline Nigeria & $99.0 \pm 18.7$ & $98.1 \pm 19.9$ & $93.2 \pm 21.4$ & $84.7 \pm 18.7$ & $110.9 \pm 27.9$ & Present study \\
\hline
\end{tabular}

be recommended that all the materials are safe for use in building construction. Table IV shows the comparison of the radium equivalent activity in this work with values obtained by other researchers from different countries of the world.

To assess the excess gamma radiation from the building materials and to further ascertain the safety of the usage of the materials in building, the gamma index $\left(\mathrm{I}_{\gamma}\right)$ was evaluated using the formula given by the European Commission as:

$$
\mathrm{I}_{\gamma}=\frac{\mathrm{A}_{\mathrm{Ra}}}{300}+\frac{\mathrm{A}_{\mathrm{Th}}}{200}+\frac{\mathrm{A}_{\mathrm{K}}}{3000} \leq 1(\mathrm{EC}, 1999) .
$$

The European Commission introduces two dose criteria for the gamma dose of building materials, which includes an exemption level (lower limit) of $0.3 \mathrm{mSv} \cdot \mathrm{y}^{-1}$ 
and an upper limit of $1.0 \mathrm{mSv}^{-1}$. If an exemption level of $0.3 \mathrm{mSv}^{-1}$ is considered, the value of $\mathrm{I}_{\gamma}$ should be below 0.5 for materials used in bulk quantities such as cement and bricks, but in the case whereby the upper limit of $1 \mathrm{mSv}^{-1} \mathrm{y}^{-1}$ is considered, the value of $\mathrm{I}_{\gamma}$ should be less than unity for bulk material usage (Mehdizadeh et al., 2011). For covering and decorative materials with restricted use such as tiles, $\mathrm{I}_{\gamma}$ should be less than 2 and 6 , supposing the control values of 0.3 and $1 \mathrm{mSv} \cdot \mathrm{y}^{-1}$, respectively. The range and mean values of $\mathrm{I}_{\gamma}$ for the five common building materials considered in this study are shown in Table III. It is observed that the highest values of $\mathrm{I}_{\gamma}$ obtained for all the building materials are higher than 0.5 but lower than the upper limit of 1.0. The mean values of the gamma index for the building materials are all lower than the 0.5 limit, indicating an excess gamma dose of less than $0.3 \mathrm{mSv} \cdot \mathrm{y}^{-1}$ for the dwellers of buildings constructed with such materials.

There is also a radiation hazard threat to respiratory organs due to ${ }^{222} \mathrm{Ra}$, and its short-lived decay products. To assess this threat, two radiation hazard indices were used in this study, which are: the internal hazard index and the alpha index. These indices are respectively given as:

$$
\begin{gathered}
\mathrm{H}_{\mathrm{in}}=\frac{\mathrm{A}_{\mathrm{Ra}}}{300}+\frac{\mathrm{A}_{\mathrm{Th}}}{200}+\frac{\mathrm{A}_{\mathrm{K}}}{3000} \text { (Otoo et al., 2011) } \\
\mathrm{I}_{\alpha}=\frac{\mathrm{A}_{\mathrm{Ra}}}{200} \text { (Tufail et al., 2007). }
\end{gathered}
$$

For the safe use of any material in the construction of dwellings, the internal hazard index should be less than or equal to unity. Also, the recommended exemption level and recommended upper limit of ${ }^{226} \mathrm{Ra}$ activity concentrations as applied in many countries of the world are $100 \mathrm{~Bq} \cdot \mathrm{kg}^{-1}$ and $200 \mathrm{~Bq} \cdot \mathrm{kg}^{-1}$, respectively (Tufail et al., 2007), which implies that the exemption level and the recommended upper limit of I are 0.5 and 1.0, respectively. If the concentration of ${ }^{226} \mathrm{Ra}$ in any building material exceeds the upper limit of $200 \mathrm{~Bq} \cdot \mathrm{kg}^{-1}$, it is not impossible that radon exhalation from the material could cause indoor radon buildup exceeding 200 Bq. $\mathrm{m}^{-3}$. As shown in Table III, the calculated mean values of $\mathrm{H}_{\text {in }}$ and $\mathrm{I}_{\alpha}$ obtained for the different building materials examined in this study are all lower than the exemption levels and far lower than the upper limit, which implies that all the building materials can be used without any restrictions.

Organs with rapidly dividing cells, e.g., gonads, the active bone marrow and bone surface cells, are known to be the most radiosensitive and are considered as organs of interest by the United Nations Scientific Committee on the Effects of Atomic Radiation (UNSCEAR, 1988). Therefore, it is important to evaluate the annual gonadal equivalent dose for dwellers of houses built with known activity concentrations of ${ }^{226} \mathrm{Ra},{ }^{232} \mathrm{Th}$ and ${ }^{40} \mathrm{~K}$. The annual gonadal equivalent dose 
(AGED) is estimated using the formula presented by Xinwei et al. (2006) and Hassan et al. (2010):

$$
\mathrm{AGED}=\left(3.09 \mathrm{~A}_{\mathrm{Ra}}+4.18 \mathrm{~A}_{\mathrm{Th}}+0.314 \mathrm{~A}_{\mathrm{K}}\right) \mu \mathrm{Sv} \cdot \mathrm{y}^{-1} .
$$

The model used for arriving at this formula was implemented for a typical cavity-type house with infinitely thick walls, thereby making it appropriate to compare the AGED of a house containing concentrations of ${ }^{226} \mathrm{Ra},{ }^{232} \mathrm{Th}$ and ${ }^{40} \mathrm{~K}$ equal to the world average values in soil $\left(25,25\right.$ and $370 \mathrm{~Bq} \cdot \mathrm{kg}^{-1}$, respectively) with those obtained using a given material (Hassan et al., 2010). The range and the mean values of the AGED evaluated for all the samples are presented in Table III, which range between $35.3 \mu \mathrm{Sv} \cdot \mathrm{y}^{-1}$ in gravel and 1003.2 $\mu \mathrm{Sv} \cdot \mathrm{y}^{-1}$ in cement. The mean values of the AGED for the five different building materials lie within a narrow range of $270.4 \mu \mathrm{Sv} \cdot \mathrm{y}^{-1}$ in bricks and $359.1 \mu \mathrm{Sv} \cdot \mathrm{y}^{-1}$ in sand.

\section{Conclusion}

The gamma spectrometric method was used for the assessment of ${ }^{40} \mathrm{~K},{ }^{226} \mathrm{Ra}$ and ${ }^{232} \mathrm{Th}$ concentrations in five commonly used building materials in southwest Nigeria. The lowest mean concentrations of ${ }^{40} \mathrm{~K}$ and ${ }^{226} \mathrm{Ra}$ were found in bricks, while the lowest mean concentration of ${ }^{232} \mathrm{Th}$ was obtained in cement. The highest mean concentrations of ${ }^{40} \mathrm{~K},{ }^{226} \mathrm{Ra}$ and ${ }^{232} \mathrm{Th}$ were found in gravel, sand and brick samples, respectively. The concentrations of the three radionuclides obtained in this study are in good agreement with the concentrations of building materials from other locations around the world. From the radiological point of view, the results of the various radiation hazard indices considered for these building materials are all lower than the maximum permissible levels. It can therefore be concluded that all the building materials are safe for use in building construction.

\section{REFERENCES}

Ackers J.G., Den-Boer J.F., De-Jong P., Wolschrijin R.A. (1985) Radioactivity and exhalation rates of building materials in the Netherlands, Sci. Tot. Environ. 45, 151-156.

Al-Jundi J., Salah W., Bawa'aneh M.S., Afaneh F. (2006) Exposure to radiation from the natural radioactivity in Jordian building materials, Radiat. Prot. Dosim. 118, 93-96.

Amrani D., Tahtat M. (2001) Natural radioactivity in Algerian building materials, Appl. Radiat. Isot. 54, 687-689.

BEIR (1999) Health Effects of Exposure to Radon. Committee on Biological Effect of Ionizing Radiation BEIR IV. National Academy Press, Washington DC.

Beretka J., Mathew P.J. (1985) Natural radioactivity of Australian building materials, industrial wastes and by-product, Health Phys. 48, 87-95.

Bou-Rabee F., Bem H. (1996) Natural radioactivity in building materials utilized in the state of Kuwait, J. Radioanal. Nucl. Chem. 213, 143-149. 
Brigido Flores O., Montalvan Estrada A., Rosa Suarez R., Tomas Zerquera J., Hernandez Perez A. (2008) Natural radioactivity content in building materials and gamma dose rate in dwellings in Cuba, J. Environ. Radioact. 99, 1834-1837.

Cliff K.D., Green B.M.R., Miles J.C.H. (1985) The levels of radioactive materials in some UK building materials, Sci. Tot. Environ. 45, 181-186.

European Commission (1999) Radiological protection principles concerning the natural radioactivity of building materials. Radiation Protection 112. EC, Brussels.

Faheem M., Mujahid S.A., Matiulla (2008) Assessment of radiological hazards due to natural radioactivity in soil and building material samples collected from six districts of Punjab province-Pakistan, Radiat. Meas. 43, 1443-1447.

Farai I.P., Ademola J.A. (2005) Radium equivalent activity concentrations in concrete building blocks in eight cities in Southwestern Nigeria, J. Environ. Radioact. 79, 119-125.

Farai I.P., Ejeh J.E. (2006) Radioactivity Concentrations in Common Brands of Cement in Nigeria, Radioprotection 41, 455-462.

Farai I.P., Isinkaye M.O. (2009) Radiological safety assessment of surface water dam sediments used as building materials in Southwestern Nigeria, J. Radiol. Prot. 29, 85-93.

Hassan N.B., Ishikawa T., Hosoda M., Sorimachi A., Tokonami S., Fukushi M., Sahoo S.K. (2010) Assessment of the natural radioactivity using two techniques for the measurement of radionuclide concentration in building materials used in Japan, J. Radioanal. Nucl. Chem. 283, 15-21.

Hayambu P., Zaman M.B., Lubaba N.C.H., Munsanje S.S., Nuleya D. (1995) Natural radioactivity in Zambia building materials collected from Lusaka, J. Radioanal. Nucl. Chem. 199, 229-238.

Hewamanna R., Sumithrachchi C.S., Mahawatte P., Nanayakkara H.L. C., Ratnayake H.C. (2001) Natural activity and gamma dose from Sri Lankan clay bricks used in building construction, Appl. Radiat. Isot. 54, 365-369.

Higgy R.H., El-Tahawy M.S., Abdel-Fattah A.T., Al-Akabawy U.A. (2000) Radionuclide content of building materials and associated gamma dose rates in Egyptian dwellings, J. Environ. Radioact. 50, 253-261.

Ingersoll G.J.A. (1983) Survey of radionuclide contents and radon emanation rates in building materials in USA, Health Phys. 45, 363-368.

Khan K., Khan H.M. (2001) Natural gamma-emitting radionuclides in Pakistani Portland cement, Appl Radiat Isot 54, 861-865.

Kobeissi M.A., El Samad O., Zahraman K., Milky S., Bahsoun F., Abumurad K.M. (2008) Natural radioactivity measurements in building meterials in Southern Lebanon, J. Environ. Radioact. 99, 1279-1288.

Krsti D., Nikezi D., Stevanovi N., Vu i D. (2007) Radioactivity of some domestic and imported building materials from South Eastern Europe, Radiat. Meas. 42, 1731-1736.

Kumar A., Kumar M., Baldev S., Singh S. (2003) Natural activities of ${ }^{238}$ U, ${ }^{232} \mathrm{Th}$ and ${ }^{40} \mathrm{~K}$ in some Indian building materials, Radiat. Meas. 36, 465-469.

Kumar V., Ramachandran T.V., Prasad R. (1999) Natural radioactivity of Indian building materials and by-products, Appl. Radiat. Isot. 51, 93-96.

Malanca A., Pessina V., Dallara G. (1993) Radionuclide-content of building materials and gamma-ray dose rates in dwellings of Rio-Grande Do-Norte Brazil, Radiat. Prot. Dosim. 48, 199-203.

Mantazul I., Chowdury M.N., Alam A.K. (1998) Concentration of radionuclides in building and ceramic materials of Bangladesh and evaluation of radiation hazard, J. Radioanal. Nucl. Chem. 231, 117-121.

Mehdizadeh S., Faghihi R., Sina S. (2011) Natural radioactivity in building materials in Iran. Nukleonika 56, 363-368. 
Nazaroff W.W., Nero Jr A.V. (Eds) (1988) Radon and its decay products in indoor air, John Wiley and Sons.

Ngachin M., Garavaglis M., Giovani C., Kwato Njock M.G., Nourreine A. (2007) Assessment of natural radioactivity and associated radiation hazards in some Cameroonian building materials, Radiat. Meas. 42, 61-67.

Otoo F., Adukpo O.K., Darko E.O., Emi-Reynolds G., Awudu A.R., Ahiamadjie H., Tandoh J.B., Hasford F., Adu S., Gyampo O. (2011) Assessment of natural radioactive materials used along the coast of Central Region of Ghana, Res. J. Environ. Earth Sci. 3, 261-268.

Papaefthymiou H., Gouseti O. (2008) Natural radioactivity and associated radiation hazards in building materials used in Peloponnese, Greece, Radiat. Meas. 43, 1453-1457.

Papastefanou C., Stoulos S., Manolopoulou M. (2005) The radioactivity of building materials, J. Radioanal. Nucl. Chem. 266, 367-372.

Righi S., Guerra R., Jeyapandian M., Verta S., Albertazzi A. (2009) Natural radioactivity in Italian ceramic tiles, Radioprotection 44, 413-419.

Rizzo S., Brai M., Basile S., Bellia S., Hauser S. (2001) Gamma activity and geochemical features of building materials; estimation of gamma dose rate and indoor radon levels in Sicily, Appl. Radiat. Isot. 55, 259-265.

Soranin H., Steger F. (1983) Natural radioactivity of building materials in Austria, Radiat. Prot. Dosim. 7, 59-61.

Stojanovska Z., Nedelkovski D., Ristova M. (2010) Natural radioactivity and human exposure by raw materials and end product from cement industry used as building materials, Radiat. Meas. 45, 969-972.

Stoulos S., Manolopoulo M., Papastefanou C. (2003) Assessment of natural radiation exposure and radon exhalation from building materials in Greece, J. Environ. Radioact. 69, 225-240.

STUK (2010) The radioactivity of building materials and ash. Giude ST12.2. Helsinki: Radiation and Nuclear Safety Authority.

Tufail M., Nasim-Akhtar, Sabiha-Javied, Hamid T. (2007) Natural radioactivity hazards of building bricks fabricated from saline soil of two districts of Pakistan, J. Radiol. Prot. 27, 481-492.

Turhan S. (2007) Assessment of the natural radioactivity and radiological hazards in Turkish cement and its raw materials, J. Environ. Radioact. 99, 404-414.

Turhan S., Baykan U.N., Sen K. (2008) Measurement of the natural radioactivity in building materials used in Ankara and assessment of external doses, J. Radiol. Prot. 28, 83-91.

UNSCEAR (1988) Sources, Effects and Risks of Ionizing Radiation. United Nations Scientific Committee on the Effects of Atomic Radiation, United Nations, New York.

UNSCEAR (2011) Sources and Effects of Ionizing Radiation. United Nations Scientific Committee on the Effects of Atomic Radiation, United Nations, Annex A \& B, New York.

Xinwei L. (2004) Natural radioactivity in some building materials and by-products of Shaanxi, China, J. Radioanal. Nucl. Chem. 262, 775-777.

Xinwei L. (2005) Natural radioactivity in some building materials of Xi'an, China, Radiat. Meas. 40, 94-97.

Xinwei L., Lingquing W., Xiaodan J. (2006) Radiometric analysis of Chine commercial granites, J. Radianal. Nucl. Chem. 267, 669-673.

Yasir M.S., Ab Majeed A., Yahaya R. (2007) Study of natural radionuclides and its radiation hazard index in Malaysian building materials, J. Radioanal. Nucl. Chem. 273, 539-541. 